\title{
THE DEVELOPMENT OF ADMINISTRATIVE LAW IN THE UNITED STATES
}

The term "Administrative Law" has no authoritative definition in English. In the third revision of Bouvier's Law Dictionary by Francis Rawle, published in I9I4, the term does not appear. 'The first book on the subject in this country, if not in English, appeared in I893. This was Professor Goodnow's "Comparative Administrative Law." In that book he says: "Of late years, with the great awakening on the continent of Europe of interest in administrative subjects, the term administrative lawin reality a simple translation of a French expression-has gradually crept into our legal vocabulary, and at the present time has obtained recognition from some of the most advanced legal thinkers. The use of the term may therefore be regarded as perfectly proper; though that use must be accompanied by an explanation." His definition of Administrative Law is as follows: "Administrative $\mathrm{Law}$ is therefore that part of the public law which fixes the organization and determines the competence of the administrative authorities, and indicates to the individual remedies for the violation of his rights." In I905, in his book on "The Principles of the Administrative Law of the United States," Professor Goodnow again defines Administrative Law as follows : "Administrative Law is therefore that part of the law which fixes the organization and determines the competence of the authorities which execute the law, and indicates to the individual remedies for the violation of his rights." On the other hand, in IgII, in the introduction to his Cases on Administrative Law, Professor Freund says: "The term 'administrative law' is sometimes applied to all provisions of law regulating matters of public administration, such as civil service, elections, municipal government, schools, public revenue, or highways. In so far as such legislation involves problems of public policy and of administrative efficiency, it concerns the student of political science and of public administration. The chief concern of administrative law, on the other hand, as of all other branches of civil law, is the protection of private rights, and its subject-matter is therefore the nature and the mode of exercise of administrative power and the system of relief against administrative action. This limitation of the subject seems conformable to the prevailing usage and under- 
standing in this country, while on the continent of Europe all positive statutory law is treated as belonging to the province of administrative law." Professor Freund's definition is narrower than Professor Goodnow's, and brings the subject within the scope of a purely legal treatise. It will therefore be accepted as defining the scope of this article.

For American lawyers, however, the term "administrative power" itself needs definition. Our constitutions, state and national, follow almost universally Montesquieu's division of the powers of government. The theory of the separation of such powers into the legislative, the executive, and the judicial, controlled our political philosophy at the time our Federal Constitution was adopted. The language of that theory is still used, but the very courts which assert the doctrine of the separation of powers, use in addition to the terms "legislative," "executive" and "judicial" power, the term, "administrative" power. Obviously if the terms "legislative," "executive" and "judicial" are sufficient to describe all the powers of the government, there is no room for any such power as the administrative power. Confusion here arises from the fact that the terms "legislative," "executive" and "judicial" are used with two distinct meanings; one historical, the other functional. Historically all the powers of government have been exercised by officers who are called executive, legislative or judicial, but there has never been any logical division of the functions of government among the officers exercising those functions. From the standpoint of the function which they perform, there are four kinds of officers, and not three, and the administrative function supplements the executive, legislative and judicial functions.

The British constitution, being unwritten and subject to change at any time by act of Parliament, has never been especially concerned with the logical division of the powers of government. The restraint of the arbitrary power of the King, the control of taxation by Parliament, the independence of the judiciary, and the responsibility of public officers to the law, are the principal features upon which the English have laid emphasis in the development of their constitution. In the United States, however, the legislative powers granted by the Constitution are vested in Congress; the executive in the President; and the judicial power in one Supreme Court and such inferior courts as Congress may from time to time ordain and establish. It was said by Chief Justice Marshall in Wayman v. Southard, Io Wheaton 1 , *46, 
that "the difference between the departments undoubtedly is, that the legislature makes, the executive executes, and the judiciary construes the law." If, then, the entire action of the sovereign were merely the making, the execution and the construction of law, the separation of powers would give no trouble. The functions of the state, however, include many other matters than the mere making and enforcing of laws. The term "law" of course, has two meanings. It may be used to denote an act of the legislative body regardless of the character of that act, or it may be used in its stricter sense of a rule established or enforced by the sovereign. In the former sense an act appropriating money for a specific object is a law. In the strict sense such an act is an administrative act. Whether or not a particular administrative act can be performed by one or the other departments of government, is a question of constitutional law depending upon the constitution of the particular sovereignty, state or federal. The essential thing to bear in mind is that the nature of the act is not affected in any way by the constitutional provision which determines by what department of the government that act must or can be performed. No case better illustrates the character of the constitutional controversy than Norzvalk Street Railway Company's Appeal, 65 Conn. 576. The court in that case held that the power of regulating the location, construction and operation of street railways given to the local municipal authorities by a Connecticut statute, clearly falls without the limits of the judicial department, and that the exercise of such a power cannot become a judicial function merely because another statute gives the railway company the right of appeal to the superior court or any judge thereof when the municipal authorities fail to exercise their powers within the limited time. The function to be exercised in that case was clearly administrative. The dissenting opinion by Judge Baldwin took the ground that the appeal might be construed to be a judicial proceeding, because the judge was bound to dispose of it in accordance with the fundamental rules of law. The difficulty in this reasoning is that there are no fundamental rules of law as to where a street railway track ought to go. The determination of what is the best location for that track in the interests of the community calls for the exercise of an administrative, and not for a judicial discretion. Judge Baldwin further maintains that even if the power be administrative, it can be constitutionally conferred on a judge of the superior court. This latter point involves simply a question of the construction 
of the particular state constitution, and that construction is largely a matter of historical consideration rather than of legal reasoning.

In the case of Prentis v. Atlantic Coast Line Co., 2II U. S. 2Io, the following principles were laid down by the United States Supreme Court:

"So far as the Federal Constitution is concerned, a state may, by constitutional provision, unite legislative and judicial powers in the same body.

A judicial inquiry investigates, declares and enforces liabilities as they stand on present or past facts and under existing laws, while legislation looks to the future and changes conditions, making new rules to be thereafter applied.

The making of a rate by a legislative body after hearing the interested parties, is not res judicata upon the validity of the rate when questioned by those parties in a suit in a court. Litigation does not arise until after legislation; nor can a state make such legislative action res judicata in subsequent litigation.

Proceedings legislative in nature are not proceedings in a court within the meaning of Rev. Stat. $\S 720$, no matter what may be the character of the body in which they take place.

Whether a railroad rate is confiscatory so as to deprive the company of its property without due process of law within the meaning of the Fourteenth Amendment depends upon the valuation of the property, the income derivable from the rate, and the proportion between the two, which are matters of fact which the company cannot be prevented from trying before a competent tribunal of its own choosing."

In this case the Court was considering the provisions of the Virginia constitution which united legislative and judicial powers in a Virginia state corporation commission. With this case should be compared a case involving the Michigan constitution, Detroit and Mackinac Railway Co. v. Michigan Railroad Commission, 235 U. S. 402, where the following principles were laid down by the Supreme Court of the United States:

"As the constitution of Michigan separates legislative, executive and judicial powers and plainly forbids giving the judicial department legislative powers, this court will not, in the absence of a decision to that effect by the state court, believe that the legislature, in establishing a railroad commission and granting power of review to the courts, intended to clothe them with power to act in a legislative 
capacity. Prentis v. Atlantic Coast Line Co., 2II U. S. 2IO, distinguished.

Under the Michigan Railroad Commission Act, as construed in the light of the provisions of the constitution of that state, the function of the supreme court of the state in reviewing an order of the Commission fixing rates is judicial and not legislative; and its final order or decree sustaining a rate established by the Commission as not confiscatory is res judicata and can be so pleaded in another action in the federal court to prevent the Commission from enforcing such rates.

Where the state court, in construing a statute of the state, has held that the establishment of rules regulating public utility corporations is a legislative function, this court, in the absence of a clear decision of the state court to the contrary, assumes that the same principle applies also to rates."

It may be worth while to give a number of instances of administrative functions, and to point out how those functions have actually been distributed among the departments of government . in different jurisdictions.

I. Appropriations: In general, appropriations are made by the legislature. In some states certain limited powers of appropriation are given to a board of state officers when the legislature is not in session. Because the administrative power of appropriation is exercised by the legislature, the legislature has assumed to regulate the administration by making appropriations in minute detail: There is no question that efficiency in administration requires that the expenditure in detail of appropriations should be left to the administrative officials, subject to a strict accounting to the legislature.

2. Licenses: The issue of licenses is an administrative matter, pure and simple. In some cases the act of the administrative officer when issuing the license, is purely ministerial, as in the case of the approval by the secretary of state of a certificate of incorporation which complies with the terms of a general corporation act. In other cases an administrative discretion is to be exercised. This is generally the case in granting licenses for the sale of liquor. In Pennsylvania, however, and perhaps in other jurisdictions the administration of the liquor license law is left to the courts.

3. The Regulation of Railway Rates: This is purely an administrative matter. This power may be exercised by the 
legislature directly, or it may be delegated to a commission, or it may be left to railway managers. ${ }^{1}$

4. The Appointment of Public Officers: Nothing is more essentially administrative than the personal appointment of a public officer. This administrative function is exercised in the greatest possible variety of ways. In the case of a large number of offices, the appointment is made directly by the people by ballot. In some cases the appointment is made by the legislature. In some cases the appointment is by the chief executive, subject to confirmation by an executive council consisting of the legislature as a whole; or of one house of the legislature, as in the case of presidential nominations, which are confirmed by the senate; or of an independent body. Some appointments are made by judges; in some states clerks and bailiffs; in some states prosecuting attorneys and police boards. The fact that the appointment is made by the legislative or judicial department, does not, of course, alter the administrative character of the function of appointment. In some cases the appointment is left to the chief or subordinate executive officer, but his discretion is limited by the legislature through civil service acts.

As already stated, whether or not a particular administrative function can be exercised by one department of the government or another, is a question of local constitutional law, the decision of which is governed by local historical considerations. How, then, does the administrative function differ from the executive and legislative and the judicial functions of the government? As between the judicial and the administrative function the distinction is clear. A judicial act necessarily involves the determination by the court of the respective rights of two or more parties whose rights are subject to the jurisdiction of the court and who are given a reasonable opportunity to appear before that court and to be heard by it from the evidence which they produce. The proceeding may be in rem, as in admiralty, in which case the seizure of the res gives the jurisdiction; or it may be quasi in rem, as in foreclosure cases, where the res is within the jurisdiction of the court, and notice is given to the owners of that res; or it may be in personam, where the defendant himself is within the jurisdiction of the court. Generally speaking, it is part of the judicial function not simply to hear the parties, but to compel the attendance of witnesses and the production of documents for the pur-

${ }^{1}$ Intermountain Rate Cases, 234 U. S. $476,486$. 
pose of the trial. From the evidence in the case the trier, whether this be judge or jury, or judge advised by a jury, finds the facts, and by applying to these facts the rules of law governing the case, the court reaches its conclusion. That conclusion, when duly announced or recorded, becomes a judgment settling the rights of the parties to the action. In some cases and within certain limits, the court has discretion as to its judgment, known as judicial discretion. When exercising this discretion, the judge is supposed to determine what is just in a particular case, when the established rule of law fixes the limits of judicial action, but does not control judicial freedom of action within those limits.

The cases are full of expressions with reference to administrative bodies in which it is said that such bodies act judicially or quasi-judicially because one or more requirements to the validity of the action of such bodies is imposed by law, such as notice, or hearing of the parties, or acting fairly and with sound discretion. Nothing could be more unfortunate than this use of the term "judicial." It is the duty of every administrative board or officer, to exercise sound discretion, although there may be no way of testing the question whether or not such discretion has been exercised. In certain cases notice, in other cases opportunity for hearing, is necessary before the administrative board or officer is entitled to take action. None of these requirements, however, in the least affect the administrative, as distinguished from the judicial character of the action taken. It would seem almost as if there were a confusion of thought between the words "judicious" and "judicial," or possibly between the use of the word "judgment" as applied to the exercise of the reasoning faculties, and the technical use of the word as applied to the decision of a cause by a judicial tribunal. Great as are the difficulties in applying the doctrine of the separation of powers under our American constitutions, no one will assert that the judicial function of government can be exercised by any other than the judicial department of the government. The judicial function is to determine the rights of parties to the cause. The administrative function is to determine the respective rights of the state, or of the public, and of those affected by the administrative action. Under the Federal Constitution no man can be deprived of his property without due process of law. Whether that due process must be administrative process or judicial process, depends upon the character of the transaction. 
The administrative function may include a portion of the legislative function. It is a maxim that legislative power cannot be delegated, but this maxim is more of a stumbling block than an aid in dealing with actual cases. Although generalizations are dangerous, it would be more accurate to say, in the present state of the law, that whenever the question whether or not a particular rule of conduct is desirable, depends upon the determination of any complicated questions of fact in so far as the conduct of the business of the community is concerned, the power to investigate those questions of fact and to enact a rule of conduct for the public benefit with relation to those facts, may be delegated by the legislature to an administrative officer, board, or commission. ${ }^{2}$

There are innumerable commissions in this country, federal and state, of which the Interstate Commerce Commission is the most important, which are authorized by legislative authority to make rules governing the conduct of business of various kinds, and the violation of those rules when made, is often declared by legislative authority to be a crime.

The administrative power may also include a portion of the executive power, and the same commission may be vested with the legislative power to enact a rule of conduct, and with the executive power of compelling compliance with that rule.

New Haven,

EDWARD A. HarrimaN.

May, I9I6.

${ }^{2}$ Intermountain Rate Cases, supra. 